\title{
Clinical impact of echocardiography parameters and molecular biomarkers in heart failure: Correlation of $A C E 2$ and $M C P-1$ polymorphisms with echocardiography parameters: A comparative study
}

\author{
MĂLINA SUCIU-PETRESCU ${ }^{1,2^{*}}$, ANAMARIA TRUTA $^{3 *}$, MIHAI DOMNUTIU SUCIU $^{4 *}$, \\ ADRIAN PAVEL TRIFA ${ }^{5}$, DENISA PETRESCU ${ }^{6}$, HORIA ȘTEFAN ROȘIANU $^{7}$, OCTAVIA SABIN $^{1}$, \\ DACIANA ELENA POPA ${ }^{7}$, ANTONIA EUGENIA MACARIE $^{8}$, \\ ȘTEFAN CRISTIAN VESA ${ }^{1}$ and ANCA DANA BUZOIANU ${ }^{1}$
}

\begin{abstract}
${ }^{1}$ Department of Pharmacology, Toxicology and Clinical Pharmacology, 'Iuliu Haţieganu’ University of Medicine and Pharmacy, 400337 Cluj-Napoca; ${ }^{2}$ Department of Cardiology, 'Regina Maria' Hospital, 400117 Cluj-Napoca;

${ }^{3}$ Research Center for Functional Genomics, Biomedicine and Translational Medicine, 'Iuliu Hațieganu' University of Medicine and Pharmacy, 400337 Cluj-Napoca; ${ }^{4}$ Department of Urology, Clinical Institute of Urology and Kidney Transplant, 'Iuliu Hatieganu' University of Medicine and Pharmacy, 400066 Cluj-Napoca; 5 Department of Medical Genetics,

'Iuliu Haţieganu' University of Medicine and Pharmacy, 400349 Cluj-Napoca; ${ }^{6}$ Department of Endocrinology, Emergency Clinical County Hospital Cluj, 'Iuliu Hatieganu' University of Medicine and Pharmacy, 400349 Cluj-Napoca; ${ }^{7}$ Department of Cardiology, 'Niculae Stăncioiu’ Heart Institute, 400001 Cluj-Napoca;

${ }^{8}$ Department of Geriatrics-Gerontology, 'Iuliu Haţieganu' University of Medicine and Pharmacy, 400139 Cluj-Napoca, Romania
\end{abstract}

Received February 5, 2021; Accepted March 8, 2021

DOI: $10.3892 /$ etm.2021.10118

\begin{abstract}
Heart failure is still the leading cause of hospitalization in patients over 65 years of age and is defined as a multifactorial pathology which involves environmental factors and also genetic predispositions. The aim of the present study was to evaluate a possible correlation between
\end{abstract}

Correspondence to: Dr Ștefan Cristian Vesa, Department of Pharmacology, Toxicology and Clinical Pharmacology, 'Iuliu Hațieganu' University of Medicine and Pharmacy, 23 Gheorghe Marinescu Street, 400337 Cluj-Napoca, Romania

E-mail: stefanvesa@gmail.com

*Contributed equally

Abbreviations: SNP, single nucleotide polymorphism; ACE2, angiotensin converting enzyme 2; MCP-1, monocyte chemoattractant protein-1; ACE, angiotensin converting enzyme; Ang, angiotensin; $\mathrm{EF}$, ejection fraction; LV, left ventricle; LA, left atrium; LVH, left ventricular hypertrophy; LVMI, left ventricular mass index; IVS, interventricular septum; PWT, inferolateral wall thickness; BMI, body mass index; BNP, B-type natriuretic peptides; NT-pro-BNP, N-terminal pro-BNP; ESC, European Society of Cardiology

Key words: ACE2 polymorphism, rs4646156, rs4646174, MCP-1 polymorphism, rs1024611, heart failure, echocardiography single nucleotide polymorphisms (SNPs) of angiotensin converting enzyme 2 (ACE2) and monocyte chemoattractant protein-1 (MCP-1) genes and cardiac remodeling in Caucasian patients diagnosed with heart failure. Our comparative translational research study included 116 patients diagnosed with heart failure and was carried out in Cluj-Napoca, Romania between September 2017 and March 2019. Three SNPs, namely rs4646156, rs4646174 and rs1024611, were genotyped using a Taqman real-time PCR technique. Our results showed that carriers of the AA genotype for ACE2 rs4646156 had a significant dilatation of the left ventricle (LV) with signs of LV hypertrophy (LVH), while TT carriers had a significant left atrial dilatation. For ACE2 rs4646174, homozygotes for the $\mathrm{C}$ allele presented a dilated LV with signs of LVH with statistical significance and had a tendency towards a lower ejection fraction. MCP-1 rs1024611 AA variant carriers had a significant LVH in the dominant model. In conclusion, our study showed a strong association between echocardiographic parameters of cardiac remodeling and SNPs rs4646156, rs4646174 of ACE2 and rs1024611 of MCP-1.

\section{Introduction}

Heart failure still represents the leading cause of hospital admission in patients over 65 years of age. It is defined as a multifactorial disease, which involves environmental factors and genetic predispositions and severely affects the quality of life of these patients (1). Genetic polymorphisms are involved 
in the pathogenesis of heart failure, but also in disease progression, and they may influence clinical outcomes or therapeutic responses (2-10).

It is well known that the renin-angiotensin system (RAS) plays an important role in heart failure progression. Angiotensin converting enzyme (ACE) converts angiotensin I (Ang I) to angiotensin II (Ang II), and angiotensin converting enzyme 2 (ACE2) cleaves Ang I into Ang-(1-9) and Ang II into Ang-(1-7). Ang II has pro-inflammatory and pro-atherosclerotic effects, and promotes hypertrophy and fibrosis, while Ang-(1-7) reduces left ventricular remodeling and the infarcted area, protects against cardiac hypertrophy, therefore having a cardioprotective effect. By having an opposite effect on the cardiovascular system, ACE and ACE2 counteract each other to regulate heart function $(1,3,11-16)$.

The ACE2 gene is located on chromosome Xp22. ACE2 is mainly expressed in cardiac tissue, the renal endothelium and in the blood vessels, and is widely expressed in human tissues and cells, except for red blood cells. Soluble ACE2 activity is a biomarker for heart failure and arterial hypertension (4,17-19). $A C E 2$ genetic variants are associated with essential hypertension (20-23), coronary artery disease (20), heart failure (13), atrial fibrillation or left atrial remodeling (20).

Research studies have confirmed that ACE2 gene polymorphism rs4646156 is associated with higher left ventricular mass and septal wall thickness, left ventricular hypertrophy (LVH) in men, diabetic-related cardiovascular complications, and a higher risk for severe pectoris angina in women (20,21,24-29). $A C E 2$ gene polymorphism rs4646174 is associated with arterial hypertension and is found frequently in patients diagnosed with pectoris angina without significant stenosis of the circumflex artery $(25,27)$.

The molecular mechanism of chronic inflammation associated with cardiac-specific expression of MCP-1 and its role in heart failure has been described in previous research studies. Experimental studies showed a correlation between $M C P-I$ expression and increased mortality in congestive heart failure. MCP-1 -2518 A>G (rs1024611) polymorphism is frequently associated with coronary artery disease, non-familial dilated cardiomyopathy, myocardial infarction, ischemic heart disease, ischemic stroke, arterial hypertension and carotid atherosclerosis in patients with type 2 diabetes, underlying the role of MCP-1 in atherosclerosis initiation, coronary artery disease and myocardial infarction (30-35).

Identifying additional components of RAS and molecular pathways involved in the pathogenesis of heart failure may lead to novel molecular biomarkers which could represent the basis in developing novel therapeutic strategies for these patients, individualized therapeutic options which might improve therapy response, clinical outcomes, survival rates and quality of life of these patients.

Based on current data regarding the association of $A C E 2$ and $M C P-1$ polymorphisms with heart failure and the importance of understanding molecular pathways underlying heart failure and targeting different genes in defining novel therapeutic strategies, our study aimed to evaluate three SNPs, ACE2 polymorphisms (rs4646156, rs4646174) and MCP-I (rs1024611) and their potential correlation with echocardiography parameters involved in cardiac remodeling in patients diagnosed with heart failure.

\section{Patients and methods}

The study was observational, prospective, cohort type. The current study included 116 patients diagnosed with heart failure and admitted to the Departments of Cardiology from 'Niculae Stancioiu' Heart Institute, Clinical Rehabilitation Hospital and Municipal Clinical Hospital of Cluj-Napoca, Romania, between November 2017 and March 2019. The inclusion criteria were: Patients aged at least 18 years with symptomatic heart failure of New York Heart Association (NYHA) functional classes II to IV, high pro-BNP values (over $300 \mathrm{pg} / \mathrm{ml}$ in an acute setting and over $125 \mathrm{pg} / \mathrm{ml}$ in a non-acute setting). Our study excluded patients with congenital heart disease, primary pulmonary hypertension, secondary arterial hypertension, pericardial disease, sepsis, malignancies, recent coronary bypass surgery and severe valvular heart disease.

Written consent was obtained from each participant after they were provided information concerning genetic testing and the study design. Confirmation of protection and integrity of personal and clinical data of the included patients was also provided. The study was approved by the Ethics Committee of 'Iuliu Hatieganu' University of Medicine and Pharmacy, Cluj-Napoca, Romania, following the rules and principles of the Helsinki Declaration. Clinical data of these patients were collected by clinical questionnaires, physical examination and medical record evaluation: Age, body mass index (BMI), comorbidities, smoking status, diameter of the left atrium (LA), left ventricular end-diastolic and end-systolic diameter (LVEDD, LVESD), ejection fraction (EF) and left ventricular mass index (LVMI). Two blood samples (2 ml EDTA) were collected for each patient. One was utilized for evaluation of total cholesterol, low-density lipoprotein, high density cholesterol, triglycerides, fasting plasma glucose, urea, serum creatinine, NT-proBNP, while the other was used for genetic testing. We performed 2D echocardiography for all patients using an Epiq7 (Phillips) or Affiniti 50 (Phillips) or Arietta 60 (Hitachi) machine. Standard parasternal and apical views were performed to assess LV and LA dimensions. The anteroposterior diameter of the LA was measured in the parasternal long-axis view using two-dimensional windows. We performed the measurements of the left ventricle and its wall from a parasternal long-axis view at the level of the mitral valve leaflet tips perpendicular to the LV long axis using two-dimensional sections. LV ejection fraction (EF) was measured using Simpson biplane formula. LV mass was calculated using the linear method and the Cube formula as following: LV mass $=0.8 \times 1.04 \times\left[(\text { IVS }+ \text { LVID+PWT })^{3}-\right.$ LVID $\left.^{3}\right]+0.6 \mathrm{~g}$. IVS is the interventricular septum, LVID is LV internal diameter and PWT is inferolateral wall thickness. LV mass was indexed to body surface area. Left ventricular hypertrophy (LVH) was defined as LV mass index (LVMI) above $95 \mathrm{~g} / \mathrm{m}^{2}$ in women and above $115 \mathrm{~g} / \mathrm{m}^{2}$ in men (36). All patients included in our study followed standard medical management according to ESC guidelines for heart failure (37).

SNP genotyping. Whole blood was collected on EDTA samples. Genomic DNA was extracted using a commercial genomic kit (PureLink Mini Genomic DNA Kit; Invitrogen, Thermo Fisher Scientific, Inc.). Genotyping was determined 
for SNPs rs1024611, rs4646156 and rs4646174 for all participants using real-time polymerase chain reaction (qPCR) performed on a QuantStudio 3 system (Applied Biosystem; Thermo Fisher Scientific, Inc.). Predesigned TaqMan probes, containing the needed primers (codes C__2551619_10, C__2551617_20, C__2590362_10, Thermo Fisher Scientific, Inc.) were used.

The used amplification regime for genotyping included a pre-read stage of $30 \mathrm{sec}$ at $60^{\circ} \mathrm{C}$, a hold stage of $10 \mathrm{~min}$ at $95^{\circ} \mathrm{C}$, a PCR stage, covering 40 cycles, each containing $15 \mathrm{sec}$ at $95^{\circ} \mathrm{C}$ and $1 \mathrm{~min}$ at $60^{\circ} \mathrm{C}$ and finally, a post-read stage of $30 \mathrm{sec}$ at $60^{\circ} \mathrm{C}$.

Statistical analysis was conducted using MedCalc Statistical Software version 19.2.1 (MedCalc Software Ltd.; https://www.medcalc.org; 2020). Quantitative data were tested for normality of distribution using the Shapiro Wilk test and were characterized by mean and standard deviation or median and 25-75 percentiles. Qualitative data are expressed as frequency and percentage. Comparisons between groups were made using the Student's t-test or Chi-square test, whenever appropriate. In order to ascertain which variables were associated with indexed LV mass, we used a multivariate linear regression. Variables that achieved a P-value of $<0.2$ in the univariate analysis, were introduced in the regression. A P-value $<0.05$ was considered statistically significant.

\section{Results}

Clinical and demographic data of the patients are reported in Table I. The mean age of the patients with heart failure was $69 \pm 8$ years, $81 \%$ had arterial hypertension, $64 \%$ associated coronary artery disease and $48 \%$ had type 2 diabetes. The clinical features of the patients according to their genotype are presented in Table II. A total of $74.1 \%$ of GG carriers of ACE2 rs4646174 presented coronary artery disease with statistical significance $(\mathrm{P}=0.01)$.

Genotype distribution of the three single nucleotide polymorphisms (SNPs) is shown in Table III.

Echocardiographic parameters for the $M C P-1$ polymorphisms are presented in Tables IV and V. No statistical differences between the three groups was observed for the analyzed echocardiographic parameters for SNP 1024611 of MCP-1. In the dominant model we observed a statistically significant association between AA homozygotes and $\mathrm{LVH}$ ( $\mathrm{P}=0.03$ for $\mathrm{LV}$ mass, $\mathrm{P}=0.04$ for indexed $\mathrm{LV}$ mass).

Echocardiographic variables for rs4646156 of ACE2 polymorphism are presented in Table VI. We observed a higher enlargement of the left atrium $(\mathrm{P}=0.007)$ for TT carriers and a dilatation of the left ventricle [end-systolic (LVESD) and end-diastolic diameters (LVEDD); $\mathrm{P}=0.003$ vs. 0.001] for homozygotes AA. We noted a higher LV mass in the same group. No significant differences regarding ejection fraction $(\mathrm{EF})$, interventricular and posterior wall dimensions of the left ventricle were observed. Homozygotes had the lowest EF of the left ventricle ranging from severe reduced EF (24.8\%) and slightly reduced EF (51.2\%), with AA homozygotes having the most affected systolic function of the LV.

Correlations of ACE2 polymorphism rs4646174 with echocardiographic parameters are presented in Table VII. We
Table I. Clinical and demographic data of the patients with heart failure in the present study.

\begin{tabular}{lc}
\hline Variables of the clinical cases & $\begin{array}{c}\text { Distribution of the } \\
\text { clinical cases }(\mathrm{N}=116) \\
\mathrm{n}(\%)\end{array}$ \\
\hline Mean age at positive diagnosis & $69 \pm 8$ years \\
Sex (M/F distribution) & \\
Male & $68(58)$ \\
Female & $48(42)$ \\
Smoking status & $57(49)$ \\
Hypertension stage & \\
Stage I & $5(5.3)$ \\
Stage II & $50(52.5)$ \\
Stage III & $40(42)$ \\
Dyslipidemia & $72(62)$ \\
Diabetes & $56(48)$ \\
Atrial fibrillation & $39(33)$ \\
Stroke & $12(10)$ \\
Obesity & $42(36)$ \\
Coronary artery disease & $75(64)$ \\
\hline
\end{tabular}

reported a statistically significant higher LVEDD and LV mass for homozygotes of the $\mathrm{C}$ allele. $\mathrm{CC}$ carriers had a tendency towards a lower $\mathrm{EF}(\mathrm{P}=0.05)$.

We analyzed the influence that the clinical and demographic variables may have on one relevant echocardiographic measurement (Table VIII). Male sex and normal body weight were statistically significant associated with a larger LVMI. Patients with coronary disease had a tendency of a higher LVMI, but the statistical threshold was slightly surpassed.

In order to ascertain which variables were associated with the LVMI, we used a multivariate linear regression (Table IX). Patients with genotypes AG or GG for MCP-1 SNP 1024611 or with obesity were more likely to have lower LVMI.

\section{Discussion}

Myocardial remodeling plays an important role in the evolution of heart failure. It involves molecular, cellular and interstitial alterations as response to cardiac damage. The clinical spectrum of manifestations includes changes in geometry, mass, cavity diameter of the left ventricle, fibrosis and inflammation. Cardiac remodeling is linked to worsening of cardiac function. In spite of reperfusion therapy of myocardial infarction and evidence based medicine for heart failure, ventricular remodeling remains independently associated with heart failure (38-45).

There is still limited data regarding the implication of angiotensin converting enzyme 2 (ACE2) and monocyte chemoattractant protein-1 $(M C P-1)$ polymorphisms in the pathophysiology of heart failure.

For $M C P-1$ rs1024611, no statistical association was observed between groups for the echocardiographic parameters, but in a dominant model (AA vs. AG+GG), AA carriers 
Table II. Clinical features of the patients according to their genotype.

\begin{tabular}{|c|c|c|c|c|c|c|}
\hline Gene/SPN & Genotype & $\begin{array}{l}\text { Males } \\
\mathrm{n}(\%)\end{array}$ & $\begin{array}{c}\text { Hypertension } \\
\mathrm{n}(\%)\end{array}$ & $\begin{array}{l}\text { Obesity } \\
\mathrm{n}(\%)\end{array}$ & $\begin{array}{c}\text { Diabetes } \\
\mathrm{n}(\%)\end{array}$ & $\begin{array}{c}\text { Coronary artery } \\
\text { disease } \mathrm{n}(\%)\end{array}$ \\
\hline \multirow[t]{4}{*}{$A C E-2 / \mathrm{rs} 4646156$} & $\mathrm{AA}$ & $27(71.1)$ & $33(86.8)$ & $12(31.6)$ & $21(38.2)$ & $23(60.5)$ \\
\hline & AT & 0 & $22(95.7)$ & $12(52.2)$ & $15(68.2)$ & $11(47.8)$ \\
\hline & TT & $42(76.4)$ & $55(70.9)$ & $18(32.7)$ & $19(50)$ & $41(74.5)$ \\
\hline & P-value & 0 & 0.21 & 0.20 & 0.56 & 0.06 \\
\hline \multirow[t]{4}{*}{$A C E-2 / \mathrm{rs} 4646174$} & $\mathrm{CC}$ & 27 (65.9) & $36(87.8)$ & 13 (31.7) & $20(48.8)$ & $26(63.4)$ \\
\hline & $\mathrm{CG}$ & 0 & $16(94.1)$ & $11(64.7)$ & $10(62.5)$ & $6(35.3)$ \\
\hline & GG & $42(72.4)$ & $42(72.4)$ & $18(31)$ & $25(43.1)$ & $43(74.1)$ \\
\hline & P-value & 0 & 0.05 & 0.13 & 0.38 & 0.01 \\
\hline \multirow[t]{4}{*}{$M C P-1 / \mathrm{rs} 1024611$} & AA & $39(60)$ & $51(78.5)$ & $23(35.4)$ & $27(42.2)$ & $42(64.6)$ \\
\hline & $\mathrm{AG}$ & $27(57.4)$ & $39(83)$ & $18(38.3)$ & $26(55.3)$ & $29(61.7)$ \\
\hline & GG & $3(75)$ & $4(100)$ & $1(25)$ & $2(50)$ & $4(100)$ \\
\hline & P-value & 0.78 & 0.51 & 0.85 & 0.39 & 0.30 \\
\hline
\end{tabular}

$A C E 2$, angiotensin converting enzyme 2; $M C P-1$, monocyte chemoattractant protein-1; SNP, single nucleotide polymorphism.

Table III. Genotype distribution of SNPs in the patients.

\begin{tabular}{|c|c|c|c|c|}
\hline \multirow{2}{*}{$\begin{array}{l}\text { Gene } \\
M C P-1\end{array}$} & \multirow{2}{*}{$\begin{array}{c}\text { SNPs } \\
\text { rs } 1024611\end{array}$} & \multicolumn{3}{|c|}{ Genotypes n (\%) } \\
\hline & & $\begin{array}{c}\text { AA } \\
65(56)\end{array}$ & $\begin{array}{c}\text { AG } \\
47(40.5)\end{array}$ & $\begin{array}{c}\mathrm{GG} \\
4(3.4)\end{array}$ \\
\hline$A C E-2$ & rs4646156 & $\begin{array}{c}\text { AA } \\
39(33.6)\end{array}$ & $\begin{array}{c}\text { AT } \\
22(18.9)\end{array}$ & $\begin{array}{c}\mathrm{TT} \\
55(47.4)\end{array}$ \\
\hline$A C E-2$ & rs4646174 & $\begin{array}{c}\mathrm{CC} \\
41(35.6)\end{array}$ & $\begin{array}{c}\mathrm{CG} \\
15(13)\end{array}$ & $\begin{array}{c}\mathrm{GG} \\
59(51.3)\end{array}$ \\
\hline
\end{tabular}

$A C E 2$, angiotensin converting enzyme 2; $M C P-1$, monocyte chemoattractant protein-1; SNPs, single nucleotide polymorphisms.

presented a significant left ventricular hypertrophy (LVH). After multivariate linear regression analysis, AA carriers associated a higher LV mass index (LVMI) in the dominant model.

LVH is an independent factor for cardiac mortality and develops in the first hours after a myocardial infarction $(43,44)$.

In a previous study analyzing a large cohort, the minor allele of $M C P-1$ polymorphism rs1799864 was associated with heart failure and myocardial infarction in patients younger than 65 years (46). The GG genotype of SNP 1024611 was previously associated with coronary artery disease susceptibility and carotid atherosclerosis $(33,47-49)$. Although all of our patients with GG genotype were associated with coronary artery disease, no further remarks regarding this observation can be made because of the small number of patients with this genotype in our study.

We observed a significant association of LV mass index (LVMI), left atrium (LA) and left ventricle (LV) dimensions with ACE2 rs4646156. Patients with AA genotype had a significant higher LVMI. Patients with TT genotype had higher LA dimensions. The association of rs4646156 and cardiovascular complication of diabetes type II was evaluated on an Uyghurs population. Our results are partially consistent with a study conducted by Liu et al, where patients with AA and AT genotypes presented significant LVH and lower ejection fraction (EF) (26).

We report in our study no statistical significance for the LVMI after multivariate linear regression analysis for the dominant model.

In our research study, there were no significant differences between groups regarding the systolic function of the LV. This finding is similar to a study by Patel et al (28) and the MONICA Augsburg echocardiographic substudy (29), where no significant differences for the systolic LV function were observed in men or women. In the MONICA Augsburg study, the rs4646156 T allele was significant associated with higher LV masses in men (29).

LA enlargement appears as a consequence of increased diastolic and systolic overloading. It can lead to the development of atrial fibrillation and has prognostic value. Some authors consider LA dilatation a marker of structural heart disease in context of left ventricular dysfunction, coronary artery disease or mitral valve diseases. An increased LA index was found to be associated with major adverse cardiac events in patients with and without atrial fibrillation (50-53). 
Table IV. Echocardiographic parameters for the codominant model for SNP of MCP-1 rs1024611.

\begin{tabular}{|c|c|c|c|c|}
\hline Echocardiographic parameters & $\begin{array}{c}\text { Mean } \pm \text { SD for } \\
\text { genotype AA }\end{array}$ & $\begin{array}{c}\text { Mean } \pm \mathrm{SD} \text { for } \\
\text { genotype } \mathrm{AG}\end{array}$ & $\begin{array}{c}\text { Mean } \pm \text { SD for } \\
\text { genotype GG }\end{array}$ & P-value \\
\hline Left atrium (mm) & $44.6 \pm 9.5$ & $44.1 \pm 5.9$ & $43.5 \pm 4$ & 0.9 \\
\hline Interventricular septum of LV (mm) & $12.3 \pm 2.2$ & $11.6 \pm 2.4$ & $10.7 \pm 4.5$ & 0.1 \\
\hline Posterior wall of LV (mm) & $11.1 \pm 1.7$ & $10.9 \pm 2$ & $11 \pm 2.4$ & 0.7 \\
\hline LVEDD (mm) & $54.4 \pm 8.4$ & $52.6 \pm 8.8$ & $55.2 \pm 11.9$ & 0.5 \\
\hline LVESD (mm) & $40.7 \pm 10.3$ & $38.8 \pm 10.5$ & $43.2 \pm 9.7$ & 0.5 \\
\hline $\mathrm{EF}(\%)$ & $41 \pm 12.4$ & $43 \pm 12.6$ & $31.8 \pm 21.6$ & 0.2 \\
\hline LV mass (g) & $263.5 \pm 71.4$ & $235.2 \pm 67.9$ & $235.5 \pm 65.1$ & 0.1 \\
\hline Indexed LV mass $\left(\mathrm{g} / \mathrm{m}^{2}\right)$ & $135.9 \pm 36.6$ & $122 \pm 36$ & $119 \pm 36.4$ & 0.1 \\
\hline
\end{tabular}

LVESD, left ventricular end-systolic diameter; LVEDD, left ventricular end-diastolic diameter; EF, ejection fraction; LV, left ventricle; $A C E 2$, angiotensin converting enzyme 2; $M C P-1$, monocyte chemoattractant protein-1; SNPs, single nucleotide polymorphisms.

Table V. Echocardiographic parameters for the dominant model for SNP of MCP-1 rs 1024611.

\begin{tabular}{lccc}
\hline $\begin{array}{l}\text { Echocardiographic parameters } \\
\text { for the dominant model }\end{array}$ & $\begin{array}{c}\text { Mean } \pm \text { SD for } \\
\text { genotype AA }\end{array}$ & $\begin{array}{c}\text { Mean } \pm \text { SD for } \\
\text { genotypes AG+GG }\end{array}$ & $44.1 \pm 5.7$ \\
\hline Left atrium $(\mathrm{mm})$ & $44.6 \pm 9.5$ & $11.5 \pm 2.5$ & 0.7 \\
IVS of LV $(\mathrm{mm})$ & $12.3 \pm 2.2$ & $10.9 \pm 2$ & 0.06 \\
Posterior wall of LV $(\mathrm{mm})$ & $11.1 \pm 1.7$ & $52.8 \pm 8.8$ & 0.4 \\
LVEDD $(\mathrm{mm})$ & $54.4 \pm 8.4$ & $39.2 \pm 10.4$ & 0.3 \\
LVESD $(\mathrm{mm})$ & $40.7 \pm 10.3$ & $42.1 \pm 13.5$ & 0.4 \\
EF $(\%)$ & $41 \pm 12.4$ & $235.2 \pm 67.1$ & 0.6 \\
LV mass $(\mathrm{g})$ & $263.5 \pm 71.4$ & $121.9 \pm 35.6$ & $\mathbf{0 . 0 3}$ \\
LVMI $\left(\mathrm{g} / \mathrm{m}^{2}\right)$ & $135.9 \pm 36.6$ & $\mathbf{0 . 0 4}$
\end{tabular}

SNP, single nucleotide polymorphism; MCP-1, monocyte chemoattractant protein-1; LV, left ventricle; IVS, interventricular septum; LVESD, left ventricular end-systolic diameter; LVEDD, left ventricular end-diastolic diameter; EF, ejection fraction, LVMI, indexed LV mass. P-values indicating significant differences are noted in bold print.

Table VI. Echocardiographic parameters for the codominant model for SNP of ACE2 rs4646156.

\begin{tabular}{|c|c|c|c|c|}
\hline Echocardiographic parameters & $\begin{array}{c}\text { Mean } \pm \text { SD for } \\
\text { Genotype AA }\end{array}$ & $\begin{array}{c}\text { Mean } \pm \text { SD for } \\
\text { Genotype AT }\end{array}$ & $\begin{array}{c}\text { Mean } \pm \text { SD for } \\
\text { genotype TT }\end{array}$ & P-value \\
\hline Left atrium (mm) & $45.1 \pm 5.9$ & $39.7 \pm 5.2$ & $45.8 \pm 9.5$ & 0.007 \\
\hline IVS of LV (mm) & $11.8 \pm 2.8$ & $11.6 \pm 2.3$ & $12.3 \pm 2.1$ & 0.41 \\
\hline Posterior wall of LV (mm) & $11.3 \pm 1.8$ & $10.8 \pm 1.7$ & $11.0 \pm 1.9$ & 0.61 \\
\hline LVEDD (mm) & $56.9 \pm 9.1$ & $48.5 \pm 6.1$ & $53.6 \pm 8.1$ & 0.001 \\
\hline LVESD (mm) & $41.8 \pm 11.4$ & $33.5 \pm 6.5$ & $41.5 \pm 9.9$ & 0.003 \\
\hline $\mathrm{EF}(\%)$ & $39.2 \pm 14.4$ & $48.5 \pm 12.2$ & $40.1 \pm 11.1$ & 0.12 \\
\hline LV mass (g) & $273.6 \pm 65.0$ & $206 \pm 59.6$ & $254.2 \pm 71.7$ & 0.01 \\
\hline $\operatorname{LVMI}\left(\mathrm{g} / \mathrm{m}^{2}\right)$ & $143.8 \pm 37.5$ & $111.1 \pm 31.7$ & $127.7 \pm 34.6$ & 0.02 \\
\hline
\end{tabular}

SNP, single nucleotide polymorphism; ACE2, angiotensin converting enzyme 2; LV, left ventricle; IVS, interventricular septum; LVESD, left ventricular end-systolic diameter; LVEDD, left ventricular end-diastolic diameter; EF, ejection fraction, LVMI, LV mass index. P-values indicating significant differences are noted in bold print.

In a study conducted by Luo et al, several SNPs of ACE2 [rs4240157, rs4830542 (CC+CT), rs4646155 (TT+CT)] were correlated with LA enlargement and the risk for atrial fibrillation, but rs4646156 was not evaluated in their study (20). 
Table VII. Echocardiographic parameters for the codominant model for SNP of ACE2 rs4646174.

\begin{tabular}{|c|c|c|c|c|}
\hline Echocardiographic parameters & $\begin{array}{c}\text { Mean } \pm \text { SD for } \\
\text { genotype CC }\end{array}$ & $\begin{array}{c}\text { Mean } \pm \text { SD for } \\
\text { genotype CG }\end{array}$ & $\begin{array}{c}\text { Mean } \pm \text { SD for } \\
\text { genotype GG }\end{array}$ & P-value \\
\hline Left atrium (mm) & $45.0 \pm 8.9$ & $39.6 \pm 5.0$ & $44.9 \pm 7.7$ & 0.27 \\
\hline IVS of LV (mm) & $11.9 \pm 2.8$ & $11.1 \pm 2.1$ & $12.3 \pm 2.1$ & 0.21 \\
\hline Posterior wall of LV (mm) & $11.4 \pm 1.6$ & $10.6 \pm 1.8$ & $10.9 \pm 2.0$ & 0.26 \\
\hline LVEDD (mm) & $56.5 \pm 9.1$ & $47.7 \pm 6.9$ & $53.5 \pm 7.8$ & 0.01 \\
\hline LVESD (mm) & $41.3 \pm 11.4$ & $33.0 \pm 7.2$ & $41.2 \pm 9.6$ & 0.09 \\
\hline $\mathrm{EF}(\%)$ & $40.2 \pm 15.0$ & $48.4 \pm 12.4$ & $40.3 \pm 10.8$ & 0.05 \\
\hline LV mass (g) & $275.6 \pm 75.3$ & $192.6 \pm 59.4$ & $250.9 \pm 60.5$ & $<0.001$ \\
\hline
\end{tabular}

SNP, single nucleotide polymorphism; ACE2, angiotensin converting enzyme 2; LV, left ventricle; IVS, interventricular septum; LVESD, left ventricular end-systolic diameter; LVEDD, left ventricular end-diastolic diameter; EF, ejection fraction. P-values indicating significant differences are noted in bold print.

To the best of our knowledge, this is the first report evaluating an association of ACE2 rs4646174 polymorphism and echocardiographic parameters in heart failure. In our study, patients with a CC genotype had significant higher LV dimensions, based on the end-diastolic diameter and a significant higher LV mass. CC carriers had a tendency towards a lower EF, but without statistical significance. GG carriers had the highest prevalence of coronary artery disease compared to the other genotypes. Further clinical experimental studies using a larger sample size are awaited to test the risk of the $\mathrm{G}$ allele for coronary artery disease and the association of the $\mathrm{C}$ allele with cardiac remodeling in different ethnic populations with different associated pathologies.

In both analyzed SNPs of $A C E 2$, homozygotes were associated with LV hypertrophy and dilatation of the LV, both consequences of adverse myocardial remodeling. Adverse reverse LV remodeling has important prognostic significance. It is an independent parameter associated with the risk of sudden cardiac death and major arrhythmic events $(54,55)$.

In previous experimental studies, ACE2 was found to be involved in modulation of cardiac function and structure. Genetic mutation of ACE2 stimulated atherosclerosis and cardiac remodeling in ACE2-knockout mice. In humans, ACE2 expression was upregulated in the ischemic failing heart, in idiopathic dilated and ischemic cardiomyopathy. In another study, plasma levels of ACE2 were found to be correlated with the severity of heart failure (56-60). Similar to other genetic studies, our study lacks data regarding plasma ACE2 levels.

Genetic variants of $A C E 2$ may influence cardiac structure in heart failure. Both tested $A C E 2$ polymorphisms from our experimental study are located in introns. Previous studies suggest that intronic polymorphism may affect gene expression and are involved in the pathophysiology of various complex disorders (61-64). How these SNPs influence the expression and function of ACE2 need to be evaluated in future experimental studies.

ACE inhibitors have significantly decreased cardiovascular mortality and hospitalizations for heart failure with left
Table VIII. Clinical variables and their influence on LVMI.

\begin{tabular}{lcc}
\hline Variables & Indexed LV mass $\left(\mathrm{g} / \mathrm{m}^{2}\right)$ & P-value \\
\hline Age & & 0.1 \\
$<65$ years & $121.1 \pm 31.7$ & \\
$\geq 65$ years & $132.2 \pm 37.8$ & \\
Sex & & $\mathbf{0 . 0 1}$ \\
Female & $119.3 \pm 35.1$ & \\
Male & $136.8 \pm 36.3$ & \\
Smoking & & 0.1 \\
Yes & $134.9 \pm 38.3$ & \\
No & $124.7 \pm 34.6$ & \\
Hypertension stage & & 0.6 \\
I & $123.6 \pm 29.3$ & \\
II & $130.6 \pm 36.3$ & \\
III & $124.3 \pm 35.7$ & \\
Dyslipidemia & & \\
No & $130.1 \pm 34.5$ & \\
Yes & $129.4 \pm 38.3$ & \\
Diabetes & & \\
No & $134.8 \pm 38$ & \\
Yes & $125.5 \pm 33$ & \\
Obesity & & \\
No & $134.7 \pm 38$ & \\
Yes & $113.9 \pm 28.2$ & \\
Coronary artery disease & & \\
No & $121.9 \pm 23.9$ & \\
Yes & $133.4 \pm 41$ & \\
\hline
\end{tabular}

LVMI, left ventricular mass index. P-values indicating significant differences are noted in bold print.

ventricular dysfunction. A proper dose selection of this therapy is an important requirement in heart failure treatment. Despite 
Table IX. Multivariate linear regression for the LVMI.

\begin{tabular}{|c|c|c|c|c|c|c|}
\hline \multirow[b]{2}{*}{ Variables } & \multicolumn{2}{|c|}{$\begin{array}{l}\text { Unstandardized } \\
\text { coefficients }\end{array}$} & \multirow[b]{2}{*}{$\mathrm{t}$} & \multirow[b]{2}{*}{ P-value } & \multicolumn{2}{|c|}{$95 \% \mathrm{CI}$ for $\mathrm{B}$} \\
\hline & $\mathrm{B}$ & Std. Error & & & Min & $\operatorname{Max}$ \\
\hline (Constant) & 280.988 & 75.902 & 3.702 & $<0.001$ & 130.505 & 431.471 \\
\hline Age $>65$ years & 11.387 & 7.827 & 1.455 & 0.149 & -4.132 & 26.906 \\
\hline Male sex & 12.696 & 7.533 & 1.685 & 0.095 & -2.239 & 27.631 \\
\hline Smoking & 6.190 & 7.041 & 0.879 & 0.381 & -7.769 & 20.150 \\
\hline Diabetes & -4.135 & 6.677 & -0.619 & 0.537 & -17.374 & 9.103 \\
\hline Obesity & -19.682 & 6.645 & -2.962 & 0.004 & -32.857 & -6.508 \\
\hline Coronary artery disease & 8.085 & 6.904 & 1.171 & 0.244 & -5.604 & 21.773 \\
\hline MCP-1 SNP 1024611 genotypes AG+GG & -12.956 & 6.404 & -2.023 & 0.046 & -25.653 & -0.259 \\
\hline$A C E 2$ rs4646156 genotypes AT+TT & -1.098 & 0.688 & -1.596 & 0.114 & -2.462 & 0.266 \\
\hline
\end{tabular}

LVMI, left ventricular mass index; $A C E 2$, angiotensin converting enzyme 2; $M C P-1$, monocyte chemoattractant protein-1; SNP, single nucleotide polymorphism. P-values indicating significant differences are noted in bold print.

an optimal treatment with ACE inhibitors, a large number of patients with heart failure present elevated Ang II levels (11). Clinical studies in the field of pharmacogenomics have revealed that antihypertensive treatment could be influenced by the ACE2 polymorphism. Female carriers of ACE2 T allele of rs2106809 have a reduced response to ACE inhibitors. In another study, Chinese female patients carrying the $\mathrm{C}$ allele of rs2106809 had a better response to ACE inhibitors $(65,66)$. New therapeutic strategies enhancing the effect of Ang 1-7 or further reducing Ang II levels may have a future in heart failure therapy.

The present study has some limitations. The cohort size was limited in order to define initially potential correlations of genetic polymorphisms with echocardiographic parameters in patients diagnosed with heart failure. Further prospective larger sample studies are needed to validate our findings and establish novel correlation with clinical features or clinical outcome in patients diagnosed with heart failure. Our study included only Caucasians and it is unknown if our results can be applied to other ethnic groups. Regarding our study design, which was clinical and volunteer based, potential bias could exist.

In conclusion, our study showed a strong association between echocardiographic parameters of cardiac remodeling and SNPs of the $A C E 2$ and $M C P-1$ genes in Caucasian patients with heart failure. ACE2 genetic polymorphism could have prognostic significance in heart failure and may also represent a target molecular biomarker for precise therapy for specific variants which might lead to future therapeutic approach in heart failure patients. Our future research studies will try to identify novel genetic variants involved in heart failure pathogenesis and define novel prognostic or diagnostic biomarkers in this pathology.

\section{Acknowledgements}

Not applicable.

\section{Funding}

The present study was supported by an institutional research grant from 'Iuliu Hatieganu' University of Medicine and Pharmacy, Cluj-Napoca, Romania (PCD 2016no. 7690/86/15.04.2016).

\section{Availability of data and materials}

The datasets used during the present study are available from the corresponding author upon reasonable request.

\section{Authors' contributions}

MSP, AT and MDS performed the literature research and drafted the manuscript. MSP, ADB and SCV designed the study. APT performed the genetic analyses. MSP, OS, DEP, AEM, and SCV acquired the data and performed data analysis and interpretation. DP and HSR contributed to overall review of the study and manuscript modification. ADB and SCV critically revised the manuscript. All authors read and approved the final manuscript.

\section{Ethics approval and consent to participate}

The study was approved by the Ethics Committee of 'Iuliu Hatieganu' University of Medicine and Pharmacy, Cluj-Napoca, Romania (registry no. 403/8.11.2017). Signed informed consent was obtained from each patient for the inclusion in this study.

\section{Patient consent for publication}

Not applicable.

\section{Competing interests}

The authors declare that they have no competing interests. 


\section{References}

1. Skrzynia C, Berg JS, Willis MS and Jensen BC: Genetics and heart failure: A concise guide for the clinician. Curr Cardiol Rev 11: 10-17, 2015.

2. Albuquerque FN, Brandão AA, Silva DA, Mourilhe-Rocha R, Duque GS, Gondar AF, Neves LM, Bittencourt MI, Pozzan R and Albuquerque DC: Angiotensin-converting enzyme genetic polymorphism: Its impact on cardiac remodeling. Arq Bras Cardiol 102: 70-79, 2014.

3. Guo M, Guo G and Ji X: Genetic polymorphisms associated with heart failure: A literature review. J Int Med Res 44: 15-29, 2016.

4. Oni-Orisan A and Lanfear DE: Pharmacogenomics in heart failure: Where are we now and how can we reach clinical application? Cardiol Rev 22: 193-198, 2014.

5. Smith JG, Felix JF, Morrison AC, Kalogeropoulos A, Trompet S, Wilk JB, Gidölf O, Wang X, Morley M, Mendelson M, et al: Discovery of genetic variation on chromosome 5q22 associated with mortality in heart failure. PLoS Genet 12: e1006034, 2016.

6. Iyngkaran P, Thomas MC, Johnson R, French J, Ilton M, McDonald P, Hare DL and Fatkin D: Contextualizing genetics for regional heart failure care. Curr Cardiol Rev 12: 231-242, 2016.

7. Beber AR, Polina ER, Biolo A, Santos BL, Gomes DC, La Porta VL, Olsen V, Clausell N, Rohde IE and Santos KG: Matrix metalloproteinase-2 polymorphisms in chronic heart failure: Relationship with susceptibility and long-term survival. PLoS One 11: e0161666, 2016.

8. Taylor MR, Sun AY, Davis G, Fiuzat M, Liggett SB and Bristow MR: Race, common genetic variation, and therapeutic response disparities in heart failure. JACC Heart Fail 2: 561-572, 2014.

9. MacRae CA: The genetics of congestive heart failure. Heart Fail Clin 6: 223-230, 2010

10. Lindgren MP, Smith JG, Li X, Sundquist J, Sundquist K and Zoller B: Familial mortality risks in patients with heart failure-A Swedish Sibling Study. J Am Heart Assoc 7: e010181, 2018.

11. Patel VB, Zhong JC, Grant MB and Oudit GY: Role of the $\mathrm{ACE} 2 /$ Angiotensin 1-7 axis of the renin-angiotensin system in heart failure. Circ Res 118: 1313-1326, 2016.

12. Hannah-Shmouni F, Seidelmann SB, Sirrs S, Mani A and Jacoby D: The genetic challenges and opportunities in advanced heart failure. Can J Cardiol 31: 1338-1350, 2015.

13. Chamsi-PashaMA, ShaoZ and Tang WH: Angiotensin-converting enzyme 2 as a therapeutic target for heart failure. Curr Heart Fail Rep 11: 58-63, 2014

14. Dadarlat A, Pop D, Procopciuc L and Buzoianu A: Links between Renin-angiotensin system genetic polymorphisms and leptin secretion in obese heart failure patients. Acta Endocrinol (Buchar) 14: 274-279, 2018.

15. Santos RAS, Sampaio WO, Alzamora AC, Motta-Santos D, Alenina N, Bader $M$ and Campagnole-Santos MJ: The ACE2/Angiotensin-(1-7)/MAS Axis of the renin-angiotensin system: Focus on Angiotensin-(1-7). Physiol Rev 98: 505-553, 2018.

16. Yang J, Feng X, Zhou Q, Cheng W, Shang C, Han P, Lin CH, Chen HS, Quertermos T and Chang CP: Pathological Ace2-to-Ace enzyme switch in the stressed heart is transcriptionally controlled by the endothelial Brg1-FoxM1 complex. Proc Natl Acad Sci USA 113: E5628-E5635, 2016.

17. Brodehl A, Ebbinghaus H, Deutsch MA, Gummert J, Gartner A, Ratnavadivel S and Milting H: Human induced pluripotent stem-cell-derived cardiomyocytes as models for genetic cardiomyopathies. Int J Mol Sci 20: 4381, 2019.

18. HuskováZ,KopkanL,ČervenkováL,DoleželováŠ, VaňourkováZ, Škaroupková P, Nishiyama A, Kompanowska-Jezierska E, Sadowski J, Kramer HJ and Cervenka L: Intrarenal alterations of the angiotensin-converting enzyme type 2/angiotensin 1-7 complex of the renin-angiotensin system do not alter the course of malignant hypertension in Cypla1-Ren-2 transgenic rats. Clin Exp Pharmacol Physiol 43: 438-449, 2016.

19. Úri K, Fagyas M, Mányiné Siket I, Kertész A, Csanádi Z, Sándorfi G, Clemens M, Fedor R, Papp Z, Édes I, et al: New perspectives in the renin-angiotensin-aldosterone system (RAAS) IV: Circulating ACE2 as a biomarker of systolic dysfunction in human hypertension and heart failure. PLoS One 9: e87845, 2014.

20. Luo Y, Liu C, Guan T, Li Y, Lai Y, Li F, Zhao M, Maimaiti T and Zeyaweiding A: Association of ACE2 genetic polymorphisms with hypertension-related target organ damages in south Xinjiang. Hypertens Res 42: 681-689, 2019.
21. Pan Y, Wang T, Li Y, Guan T, Lai Y, Shen Y, Zeyaweiding A, Maimaiti T, Li F, Zhao H and Liu C: Association of ACE2 polymorphisms with susceptibility to essential hypertension and dyslipidemia in Xinjiang, China. Lipids Health Dis 17: 241, 2018.

22. He Y, Yang W, Liu S, Gan L, Zhang F, Mu C, Wang J, Qu L, Wang R, Deng $\mathrm{J}$, et al: Interactions between angiotensin-converting enzyme-2 polymorphisms and high salt intake increase the risk of hypertension in the Chinese Wa population. Int J Clin Exp Pathol 10: 11159-11168, 2017.

23. Bosso M, Thanaraj TA, Abu-Farha M, Alanbaei M, Abubaker J and Al-Mulla F: The two faces of ACE2: The role of ACE2 receptor and its polymorphisms in hypertension and COVID-19. Mol Ther Methods Clin Dev 18: 321-327, 2020.

24. Liu D, Chen Y, Zhang P, Zhong J, Jin L, Zhang C, Liu S, $\mathrm{Wu} \mathrm{S}$ and $\mathrm{Yu} \mathrm{H}$ : Association between circulating levels of ACE2-Ang-(1-7)-MAS axis and ACE2 gene polymorphisms in hypertensive patients. Medicine (Baltimore) 95: e3876, 2016.

25. Patel SK, Velkoska E, Freeman M, Wai B, Lancefield TF and Burrell LM: From gene to protein-experimental and clinical studies of ACE2 in blood pressure control and arterial hypertension. Front Physiol 5: 227, 2014.

26. Liu C, Li Y, Guan T, Lai Y, Shen Y, Zeyaweiding A, Zhao H, Li F and Maimaiti T: ACE2 polymorphisms associated with cardiovascular risk in Uygurs with type 2 diabetes mellitus. Cardiovasc Diabetol 17: 127, 2018

27. Vašků A, Bienertová-Vašků J, Pařenica J, Goldbergová MP, Lipková J, Zlámal F, Kala P and Spinar J: ACE2 gene polymorphisms and invasively measured central pulse pressure in cardiac patients indicated for coronarography. J Renin Angiotensin Aldosterone Syst 14: 220-226, 2013.

28. Patel SK, Wai B, Ord M, MacIsaac RJ, Grant S, Velkoska E, Panagiotopoulos S, Jerums G, Srivastava PM and Burrell LM: Association of ACE2 genetic variants with blood pressure, left ventricular mass, and cardiac function in Caucasians with type 2 diabetes. Am J Hypertens 25: 216-222, 2012.

29. Lieb W, Graf J, Götz A, König IR, Mayer B, Fischer M, Stritzke J, Hengstenberg C, Holmer SR, Döring A, et al: Association of angiotensin-converting enzyme 2 (ACE2) gene polymorphisms with parameters of left ventricular hypertrophy in men. Results of the MONICA Augsburg echocardiographic substudy. J Mol Med (Berl) 84: 88-96, 2006.

30. Niu J, Azfer A, Deucher MF, Goldschmidt-Clermont PJ and Kolattukudy PE: Targeted cardiac expression of soluble Fas prevents the development of heart failure in mice with cardiac-specific expression of MCP-1. J Mol Cell Cardiol 40: 810-820, 2006

31. Matsuda S, Umemoto S, Yoshimura K, Itoh S, Murata T, Fukai T and Matsuzaki M: Angiotensin activates MCP-1 and induces cardiac hypertrophy and dysfunction via toll-like receptor 4. J Atheroscler Thromb 22: 833-844, 2015.

32. Piotrowski P, Lianeri M, Gasik R, Roszak A, Olesińska M and Jagodziński PP: Monocyte chemoattractant protein-1 -2518 A/G single nucleotide polymorphism might be associated with renal disease and thrombocytopenia of SLE. J Biomed Biotechnol 2010: 130265, 2010.

33. Kaur R, Matharoo K, Arora P and Bhanwer AJ: Association of $-2518 \mathrm{~A}>\mathrm{G}$ promoter polymorphism in the monocyte chemoattractant protein-1 (MCP-1) gene with type 2 diabetes and coronary artery disease. Genet Test Mol Biomarkers 17: 750-755, 2013.

34. Penz P, Bucova M, Lietava J, Blazicek P, Paulovicova E, Mrazek F, Bernadic M, Buckingham TA and Petrek M: MCP-1 $-2518 \mathrm{~A} / \mathrm{G}$ gene polymorphism is associated with blood pressure in ischemic heart disease asymptomatic subjects. Bratisl Lek Listy 111: 420-425, 2010.

35. Cai G, Zhang B, Weng W, Shi G and Huang Z: The associations between the MCP-1 -2518 A/G polymorphism and ischemic heart disease and ischemic stroke: A meta-analysis of 28 research studies involving 21,524 individuals. Mol Biol Rep 42: 997-1012, 2015.

36. Lang RM, Badano LP, Mor-Avi V, Afilalo J, Armstrong A, Ernande L, Flachskampf FA, Foster E, Goldstein SA, Kuznetsova T, et al: Recommendations for cardiac chamber quantification by echocardiography in adults: An update from the American Society of Echocardiography and the European Association of Cardiovascular Imaging. Eur Heart J Cardiovasc Imaging 16: 233-270, 2015. 
37. Ponikowski P, Voors AA, Anker SD, Bueno H, Cleland JG, Coats AJ, Falk V, González-Juanatey JR, Harjola VP, Jankowska EA, et al: 2016 ESC Guidelines for the diagnosis and treatment of acute and chronic heart failure: The Task Force for the diagnosis and treatment of acute and chronic heart failure of the European Society of Cardiology (ESC)Developed with the special contribution of the Heart Failure Association (HFA) of the ESC. Eur Heart J 37: 2129-2200, 2016.

38. Takano H, Hasegawa H, Nagai T and Komuro I: Implication of cardiac remodeling in heart failure: Mechanisms and therapeutic strategies. Intern Med 42: 465-469, 2003.

39. Konstam MA, Kronenberg MW, Rousseau MF, Udelson JE, Melin J, Stewart D, Dolan N, Edens TR, Ahn S, Kinan D, et al: Effects of the angiotensin converting enzyme inhibitor enalapril on the long-term progression of left ventricular dilatation in patients with asymptomatic systolic dysfunction. SOLVD (Studies of Left Ventricular Dysfunction) Investigators. Circulation 88: 2277-2283, 1993.

40. Doughty RN, Whalley GA, Gamble G, MacMahon S and Sharpe N: Effects of carvedilol on left ventricular regional wall motion in patients with heart failure caused by ischemic heart disease. Australia-New Zealand Heart Failure Research Collaborative Group. J Card Fail 6: 11-18, 2000.

41. Colucci WS, Kolias TJ, Adams KF, Armstrong WF, Ghali JK, Gottlieb SS, Greenberg B, Kilbaner MI, Kukin ML and Sugg JE; REVERT Study Group: Metoprolol reverses left ventricular remodeling in patients with asymptomatic systolic dysfunction: The REversal of VEntricular Remodeling with Toprol-XL (REVERT) trial. Circulation 116: 49-56, 2007.

42. Waagstein F, Strömblad O, Andersson B, Böhm M, Darius M, Delius W, Goss F, Osterziel KJ, Sigmund M, Trenkwalder SP and Wahlqvist I: Increased exercise ejection fraction and reversed remodeling after long-term treatment with metoprolol in congestive heart failure: A randomized, stratified, double-blind, placebo-controlled trial in mild to moderate heart failure due to ischemic or idiopathic dilated cardiomyopathy. Eur J Heart Fail 5: 679-691, 2003

43. Cohn JN, Ferrari R and Sharpe N: Cardiac remodeling-concepts and clinical implications: A consensus paper from an international forum on cardiac remodeling. Behalf of an International Forum on Cardiac Remodeling. J Am Coll Cardiol 35: 569-582, 2000.

44. Ferrario CM: Cardiac remodelling and RAS inhibition. Ther Adv Cardiovasc Dis 10: 162-171, 2016.

45. Bauters C, Dubois E, Porouchani S, Saloux E, Fertin M, de Groote P, Lamblin N and Pinet F: Long-term prognostic impact of left ventricular remodeling after a first myocardial infarction in modern clinical practice. PLoS One 12: e0188884, 2017.

46. Ortlepp JR, Vesper K, Mevissen V, Schmitz F, Janssens U, Franke A, Hanrath P, Weber C, Zerres K and Hoffmann R: Chemokine receptor (CCR2) genotype is associated with myocardial infarction and heart failure in patients under 65 years of age. J Mol Med (Berl) 81: 363-367, 2003.

47. Szalai C, Duba J, Prohászka Z, Kalina A, Szabó T, Nagy B, Horváth L and Császár A: Involvement of polymorphisms in the chemokine system in the susceptibility for coronary artery disease (CAD). Coincidence of elevated Lp(a) and MCP-1 -2518 G/G genotype in CAD patients. Atherosclerosis 158: 233-239, 2001.

48. Nyquist PA, Winkler CA, McKenzie LM, Yanek LR, Becker LC and Becker DM: Single nucleotide polymorphisms in monocyte chemoattractant protein-1 and its receptor act synergistically to increase the risk of carotid atherosclerosis. Cerebrovasc Dis 28: 124-130, 2009.

49. Kerget B, Araz O, Erdem HB and Akgün M: The frequency of monocyte chemoattractant protein-1 gene polymorphism in obstructive sleep apnea syndrome. Lung 197: 585-592, 2019.

50. Sardana M, Lessard D, Tsao CW, Parikh NI, Barton BA, Nah G, Thomas RC, Cheng S, Schiller NB, Aragam JR, et al: Association of left atrial function index with atrial fibrillation and cardiovascular disease: The Framingham Offspring Study. Journal of the American Heart Association 7, 2018.
51. Froehlich L, Meyre P, Aeschbacher S, Blum S, Djokic D, Kuehne M, Osswald S, Kaufmann BA and Conen D: Left atrial dimension and cardiovascular outcomes in patients with and without atrial fibrillation: A systematic review and meta-analysis. Heart 105: 1884-1891, 2019.

52. Vaziri SM, Larson MG, Lauer MS, Benjamin EJ and Levy D Influence of blood pressure on left atrial size. The Framingham Heart Study. Hypertension 25: 1155-1160, 1995.

53. Rusinaru D, Tribouilloy C, Grigioni F, Avierinos JF, Suri RM, Barbieri A, Szymanski C, Ferlito M, Michelena H, Tafanelli L, et al: Left atrial size is a potent predictor of mortality in mitral regurgitation due to flail leaflets: Results from a large international multicenter study. Circ Cardiovasc Imaging 4: 473-481, 2011.

54. Shenasa $M$ and Shenasa $H$ : Hypertension, left ventricular hypertrophy, and sudden cardiac death. Int J Cardiol 237: 60-63, 2017.

55. Stewart MH, Lavie CJ, Shah S, Englert J, Gilliland Y, Qamruddin S, Dinshaw H, Cash M, Ventura H and Milani R: Prognostic implications of left ventricular hypertrophy. Prog Cardiovasc Dis 61: 446-455, 2018.

56. Thomas MC, Pickering RJ, Tsorotes D, Koitka A, Sheehy K, Bernardi S, Toffoli B, Nguyen-Huu TC, Head GA, Fu Y, et al: Genetic Ace2 deficiency accentuates vascular inflammation and atherosclerosis in the ApoE knockout mouse. Circ Res 107: 888-897, 2010.

57. Alghamri MS, Weir NM, Anstadt MP, Elased KM, Gurley SB and Morris M: Enhanced angiotensin II-induced cardiac and aortic remodeling in ACE2 knockout mice. J Cardiovasc Pharmacol Ther 18: 138-151, 2013.

58. Goulter AB, Goddard MJ, Allen JC and Clark KL: ACE2 gene expression is up-regulated in the human failing heart. BMC Med 2: 19, 2004

59. Burrell LM, Risvanis J, Kubota E, Dean RG, MacDonald PS, Lu S, Tikellis C, Grant SL, Lew RA, Smith AI, et al: Myocardial infarction increases ACE2 expression in rat and humans. Eur Heart J 26: 369-375; discussion 22-24, 2005.

60. Epelman S, Tang WH, Chen SY, Van Lente F, Francis GS and Sen S: Detection of soluble angiotensin-converting enzyme 2 in heart failure: Insights into the endogenous counter-regulatory pathway of the renin-angiotensin-aldosterone system. J Am Coll Cardiol 52: 750-754, 2008.

61. Blackwood EM and Kadonaga JT: Going the distance: A current view of enhancer action. Science 281: 60-63, 1998.

62. Horikawa Y, Oda N, Cox NJ, Li X, Orho-Melander M, Hara M, Hinokio Y, Lindner TH, Mashima H, Schwarz PE, et al: Genetic variation in the gene encoding calpain-10 is associated with type 2 diabetes mellitus. Nat Genet 26: 163-175, 2000.

63. Tokuhiro S, Yamada R, Chang X, Suzuki A, Kochi Y, Sawada T, Suzuki M, Nagasaki M, Ohtsuki M, Ono M, et al: An intronic SNP in a RUNX1 binding site of SLC22A4, encoding an organic cation transporter, is associated with rheumatoid arthritis. Nat Genet 35: 341-348, 2003.

64. Zhao Q, Gu D, Kelly TN, Hixson JE, Rao DC, Jaquish CE, Chen J, Huang J, Chen CS, Gu CC, et al: Association of genetic variants in the apelin-APJ system and ACE2 with blood pressure responses to potassium supplementation: The GenSalt study. Am J Hypertens 23: 606-613, 2010.

65. Fan X, Wang Y, Sun K, Zhang W, Yang X, Wang S, Zhen Y, Wang J, Li W, Han Y, et al: Polymorphisms of ACE2 gene are associated with essential hypertension and antihypertensive effects of Captopril in women. Clin Pharmacol Ther 82: 187-196, 2007.

66. Chen YY, Liu D, Zhang P, Zhong JC, Zhang CJ, Wu SL, Zhang YQ, Liu GZ, He M, Jin LJ and Yu HM: Impact of ACE2 gene polymorphism on antihypertensive efficacy of ACE inhibitors. J Hum Hypertens 30: 766-771, 2016. 